\title{
Impact of the mHealth strategy in sodium consumption markers: AvaliaSal Study
}

\section{Impacto da estratégia mHealth em marcadores do consumo de sódio: Estudo AvaliaSal}

\author{
Aline Silva PORTO 1 (D) 0000-0002-4780-3228 \\ Haysla Xavier MARTINS1 (D) 0000-0001-8827-1793 \\ Carolina Perim de FARIA ${ }^{1}$ (D) 0000-0001-9165-1332 \\ Maria del Carmen Bisi MOLINA ${ }^{1}$ (D) 0000-0002-8614-988X
}

\section{A B S T R A C T}

\section{Objective}

Evaluate the effectiveness of mHealth strategy on sodium consumption markers.

\section{Methods}

Intervention study carried out with 175 adults (20-59 years), from an educational institution of Vitória, Espirito Santo State. Participants were made aware through posters, oral approach and electronic media. Anthropometric, hemodynamic, socioeconomic, health, and dietary practices data was collected in two stages. After the first assessment, participants were randomized into two groups: Intervention Group and Control Group. The Intervention Group included 21 electronic messages and 3 videos on healthy eating focusing on the goal to reduce sodium intake for 3 months. Behavioral changes were assessed using the Generalized Estimation Equation ( $p$-value $<0.05$ ).

\section{Results}

At baseline, no significant differences in socioeconomic, anthropometric and health variables, and eating practices between groups were observed. The stock broth cube was the most used ready processed seasoning. After the intervention, a reduction in the use of stock broth was observed only in the intervention group

\footnotetext{
1 Universidade Federal do Espírito Santo, Centro de Ciências da Saúde, Programa de Pós-Graduação em Nutrição e Saúde. Av. Marechal Campos, n. 1468, Maruípe, 29043-900 Vitória, ES, Brasil. Correspondence to: M. C. B. MOLINA. E-mail: $<$ mdcarmen2007@gmail>.

Support: Coordenação de Aperfeiçoamento de Pessoal de Nivel Superior (CAPES, Coordination for the Improvement of Higher Education Personnel).

Article elaborated from dissertation by A. S. PORTO, entitled "Impacto de um programa de saúde via Mobile Health sobre mudança de comportamento em relação ao consumo de sal". Universidade Federal do Espírito Santo, Vitória; 2019.
}

How to cite this article

Porto AS, Martins HX, Faria CP, Molina MCB. Impact of the mHealth strategy in reducing sodium consumption markers: AvaliaSal Study. Rev Nutr. 2020;33:e200026. https://doi.org/10.1590/1678-9865202032e200026 
$(\beta=0.615 ; p=0.016)$. In addition, $73 \%$ of the intervention group participants reported that the messages were clear, $67 \%$ reported that they were useful, and $48 \%$ stated they followed the guidelines.

\section{Conclusion}

There was a reduction in the frequency of use of stock broth cubes, demonstrating the potential effect of the $\mathrm{m}$-Health strategy on sodium consumption markers in individuals without a hypertension medical diagnosis.

Keywords: Food consumption. Industrialized food. Intervention study. Sodium.

\section{R E S U M O}

\section{Objetivo}

Avaliar a efetividade da estratégia mHealth sobre marcadores do consumo de sódio.

\section{Métodos}

Estudo de intervenção realizado com 175 adultos (20-59 anos), vinculados a uma instituição de ensino de Vitória, no Estado do Espirito Santo. Os participantes foram contatados por através da exposição a de um pôster, de abordagem oral e mídia eletrônica. Dados antropométricos, hemodinâmicos, socioeconômicos, de saúde e práticas alimentares foram coletados em dois momentos. Os participantes foram randomizados em dois grupos: Grupo de Intervenção e Grupo de Controle. Durante a intervenção, que durou três meses, os participantes receberam 21 mensagens eletrônicas e assistiram a três vídeos sobre alimentação saudável, com foco na redução do consumo de sódio. Mudanças foram avaliadas por Equação de Estimativa Generalizada e adoção de valor de $p<0,05$.

\section{Resultados}

Na linha de base, não foram observadas diferenças significativas em relação às variáveis antropométricas, socioeconômicas, de saúde e práticas alimentares entre os grupos. Caldo pronto foi o condimento industrializado mais utilizado pelos participantes durante o estudo. Foi observada uma redução do uso de caldo pronto apenas no Grupo de Intervenção (=0,615; $p=0,016)$. Além disso, 73\% do Gruo de Intervenção relataram que as mensagens foram claras; $67 \%$ afirmaram que as mensagens foram úteis e $48 \%$ disseram que seguiram as orientações.

\section{Conclusão}

Foi observada uma redução da frequência do uso de caldo pronto, demonstrando potencial da estratégia $m$-Health sobre marcadores do consumo de sódio em participantes sem diagnóstico de hipertensão.

Palavras-chave: Consumo de alimentos. Alimentos industrializados. Estudo de intervenção. Sódio.

\section{NTRODUCTION}

High sodium consumption is one of the risk factors in hypertension and cardiovascular diseases, and is associated with a higher overall mortality [1]. In the United Kingdom, 56.8\% of the total calories intake comes from the consumption of ultra-processed foods and is associated with increased sodium intake [2]. In other countries, such as India and Japan, most of the sodium comes from salt addition and the use of table salt, a habit also observed in Brazil $[3,4]$. Despite this, the consumption of ultra-processed foods, which are important sources of sodium, has also been growing in Brazil, contributing with $20.4 \%$ of the total food consumed [5].

In a study carried out in 2016 with 517 adults (20-80 years) living in Arthur Nogueira, São Paulo State, using the sodium urinary excretion method and dietary data, an estimated salt consumption of $10.5 \mathrm{~g}$ and $11 \mathrm{~g}$ was found, respectively. The authors also identified that the main source of sodium, about 68\%, came from the salt added during food preparation [4]. A similar estimate of salt consumption $(10.5 \pm 3.6 \mathrm{~g})$ was found in the study carried out in Vitória, Espírito Santo State, that is, twice the daily recommended rate. In addition, individuals who used stock broth cubes and dressings daily exhibited sodium urinary excretion approximately $25 \%$ above those who used such products 
occasionally [6]. This scenario shows the importance and the need to implement actions to reduce the addition of salt and processed seasonings using different approaches.

A strategy that has been adopted in many countries to care and foster health is the Mobile Health (m-Health) technology, which is carried out through the use of smartphones, videos, e-mails, reminders, telephone calls, among others. Bearing in mind that it is low cost, quick to apply and accessible, the $\mathrm{m}$-Health strategy could be used to encourage healthier eating habits, among which is the reduction of sodium consumption [7].

In England, intervention using the m-Health strategy with hypertensive individuals was effective in reducing blood pressure [8]. The same result was observed with hypertensive patients in Argentina and South Africa $[9,10]$. However, studies in normotensive individuals are still scarce [11]. Considering that reducing sodium consumption is one of the goals for promoting healthy eating, we ought to encourage habits changes in the general population and not only in individuals with a disease. Thus, the objective of this study was to evaluate the effect of the use of the m-Health strategy on sodium consumption markers in adults without a hypertension medical diagnosis.

\section{METHODS}

Intervention study (AvaliaSal Study) conducted with civil servants and students from an educational institution in Vitória/ES Brazil. All officers and students aged between 20 and 59 years were included in the study. Participants who reported a medical diagnosis of hypertension in the first screening $(n=25)$ were excluded from the study.

A total of 200 adults were recruited in 2017, through a publicity campaign using posters and oral approach in the institution's courtyard, e-mail sent to the institution's staff and to the students and through the institution social network $\left(\right.$ Facebook $\left.^{\circledR}\right)$ [12]. After the first assessment, randomization by cluster was performed, in two levels of categories: gender (female and male) and age group ( $<40$ years or $\geq 40$ years) and two groups were established: Intervention Group (IG) and Control Group (CG).

Data was collected in a room dedicated to this study, located in the medical and dental service of the educational institution, at two time points, by trained and certified investigators. The total duration of the study was 16 months, as follows: $1^{\text {st }}$ evaluation: March-June/2017; Intervention planning: July-September, 2017; IG intervention: October-December, 2017, $2^{\text {nd }}$ evaluation: January-April, 2018; CG Intervention: May-June, 2018.

Body weight was measured on a digital scale with $136 \mathrm{~kg}$ capacity and $100 \mathrm{~g}$ accuracy and height measured on a portable stadiometer with a $200 \mathrm{~cm}$ amplitude and $1 \mathrm{~mm}$ precision. Participants were classified, according to the Body Mass Index (BMI), as eutrophic $\left(\mathrm{BMI}<25 \mathrm{~kg} / \mathrm{m}^{2}\right)$ or overweight $\left(\mathrm{BMI} \geq 25 \mathrm{~kg} / \mathrm{m}^{2}\right)$.

Blood Pressure (BP) was measured according to the protocol of the Sociedade Brasileira de Cardiologia (Brazilian Society of Cardiology) [13]. The participant was kept in a seating position for 5 minutes, and after this the BP was measured three times, with an interval of 2 minutes between measurements. The arithmetic mean of the last two measurements was considered.

Sociodemographic, health and dietary data was collected using a structured questionnaire prepared by the investigators themselves. The questionnaire on dietary practices included questions related to the following aspects: change in eating habits in the last 6 months, habit of eating out, 
use of different processed seasonings, use of different natural condiments, addition of salt in the food prepared or in salads, use of salt shaker at the table and consumption of fresh food. The socioeconomic class was determined as proposed by the Brazilian Association of Research Companies and race/skin color was self-reported [14]. In the second evaluation, objective questions about the participant's perception of the messages and videos distributed were included in the questionnaire.

The intervention consisted in sending 21 messages and 3 videos, according to the participant's preference (Whatsapp ${ }^{\circledast}$ or e-mail), about the benefits of using natural seasonings and healthy eating habits, and the harms of using processed seasonings and excess salt in the diet [15]. The messages or videos were sent twice a week to the participants (Monday and Friday), for three months. Examples of these messages are: "The use of natural herbal salt can contribute to reducing your daily salt intake" and "Animal foods already contain sodium. When processed, they increase their content even more". To develop the messages, the Food Guide for the Brazilian Population and the Reference Landmark of Food and Nutrition Education for Public Policies were used [16,17]. Two 8-hour workshops were also held, with the advice from a specialized nutritionist, for planning the intervention proposal. After reassessment, the $C G$ received the same intervention.

For data analysis, the Kolmogorov-Smirnov, Chi-square statistical test, mcNemar test, Student's $t$ test and Mann-Whitney test were used. Change over time was assessed by the Generalized Estimation Equation (GEE). This test is suitable for analysis between and within groups in longitudinal studies. The following variables were included in the test (GEE): Stock broth cubes (Multinominal variable); Times (Evaluation or Revaluation); Group (Intervention or Control). Adjustment variables were not used.

In view of the loss of $37(21.1 \%)$ participants before the second assessment, the data from the first observation was imputed, repeating the baseline measurements. To minimize the effects of the loss of participants' follow-up, an Intention-to-Treat analysis was performed.

All analyses were carried out using the Statistical Package for the Social Sciences (SPSS, version 23) and the significance level was set at 5\% [18].

This study was approved by the UFES Research Ethics Committee (n. 1,789,812/2016), at the World Health Organization (UTN n. U111112146330), and was submitted to the Registro Brasileiro de Ensaios Clínicos (Brazilian Registry of Clinical Trials) (RBR-9s6jpc). All participants signed the Free and Informed Consent Form.

\section{RE S U L T S}

A total of 175 adults participated in the study; the mean age was $32.5 \pm 10.9$ years; 87 individuals were in the Intervention Group and 88 in the Control Group, after excluding participants with a medical diagnosis of hypertension (Figure 1). In the second assessment, 37 (21.1\%) participants failed to attend, as follows: 9 did not answer the phone call, 22 were considered withdrawals after 3 attempts to scheduling the visit and 6 withdrew from the study. Out of the 37 participants who did not undergo the second assessment, 21 belonged to the IG and 16 to the CG; the majority included male individuals $(54.1 \%)$, non-white $(64.9 \%)$, socioeconomic class B $(54.1 \%)$ and had high school education (54.1\%). After sensitivity analysis, no difference was found for any of the sociodemographic variables, that is, the groups remained similar regarding age, gender and education.

No significant difference between groups at baseline was observed in any sociodemographic or health variable (Table 1), nor in relation to eating practices (Table 2). Among the most used processed seasonings, the ready stock broth cube stood out (over $50 \%$ used the stock broth cube daily or weekly). 


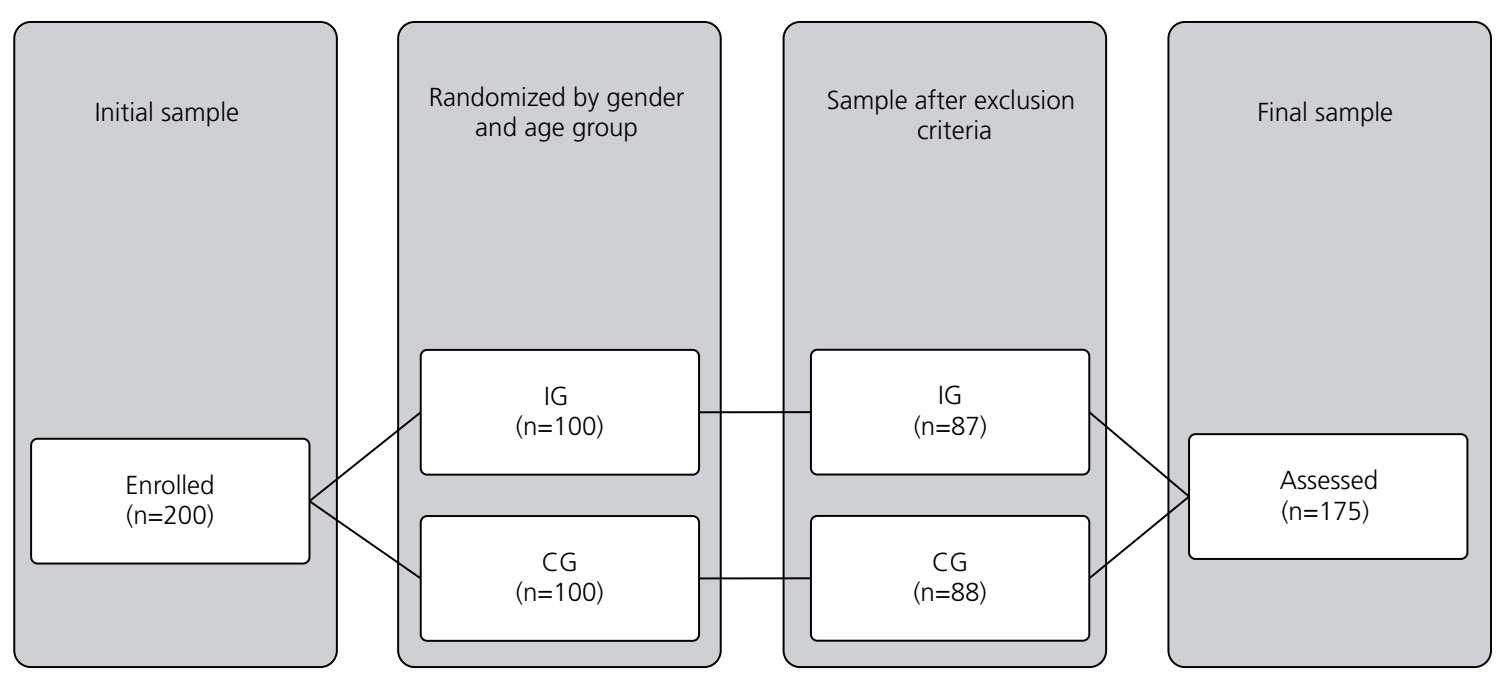

Figure 1. Assessment flowchart. AvaliaSal Study, Vitória (ES), Brazil, 2017-2018.

Table 1. Distribution of participants at baseline, according to allocation group. AvaliaSal Study. Vitória (ES), Brazil, 2017-2018.

\begin{tabular}{|c|c|c|c|c|c|}
\hline \multirow{3}{*}{ Variable } & \multicolumn{4}{|c|}{ Allocation Group } & \multirow{3}{*}{$p$-value } \\
\hline & \multicolumn{2}{|c|}{ Intervention $(\mathrm{n}=87)$} & \multicolumn{2}{|c|}{ Control $(n=88)$} & \\
\hline & $\mathrm{n}$ & $\%$ & $n$ & $\%$ & \\
\hline Gender $^{a}$ & & & & & 0.827 \\
\hline Male $(n=75)$ & 38 & 43.7 & 37 & 42.0 & - \\
\hline Female $(n=100)$ & 49 & 56.3 & 51 & 58.0 & - \\
\hline Education ${ }^{a}$ & - & - & - & - & 0.398 \\
\hline Primary/secondary $(n=97)$ & 51 & 58.6 & 46 & 52.3 & - \\
\hline College/Post-graduation $(n=78)$ & 36 & 41.4 & 42 & 47.7 & - \\
\hline Race/skin color ${ }^{\mathbf{a}}$ & - & - & - & - & 0.150 \\
\hline White $(n=86)$ & 38 & 43.7 & 48 & 54.5 & - \\
\hline Non white $(\mathrm{n}=89)$ & 49 & 56.3 & 40 & 45.5 & - \\
\hline Socioeconomic class $^{\mathbf{a}}$ & - & - & - & - & 0.373 \\
\hline$A(n=64)$ & 30 & 34.5 & 32 & 36.4 & - \\
\hline$B(n=91)$ & 43 & 49.4 & 48 & 54.5 & - \\
\hline$C(n=22)$ & 14 & 16.1 & 8 & 9.1 & - \\
\hline Body Mass Index ${ }^{a}$ & - & - & - & - & 0.325 \\
\hline \multirow{3}{*}{$\begin{array}{l}<25 \mathrm{Kg} / \mathrm{m}^{2}(n=103) \\
\geq 25 \mathrm{Kg} / \mathrm{m}^{2}(n=72)\end{array}$} & 48 & 55.2 & 55 & 62.5 & - \\
\hline & 39 & 44.8 & 33 & 37.5 & - \\
\hline & $\mathrm{Md}$ & $\mathrm{Cl}$ & $\mathrm{Md}$ & $\mathrm{Cl}$ & $p$-value \\
\hline Age (years) ${ }^{\mathbf{b}}$ & 29.0 & $29.8-34.5$ & 29.5 & $30.6-32.5$ & 0.544 \\
\hline BMI $\left(\mathrm{kg} / \mathrm{m}^{2}\right)^{\mathbf{b}}$ & 24.1 & $23.7-25.5$ & 23.8 & $23.3-25.4$ & 0.872 \\
\hline $\mathrm{SBP}(\mathrm{mm} \mathrm{Hg})^{c}$ & 114 & 114-120 & 114 & $114-120$ & 0.867 \\
\hline $\operatorname{DBP}\left(\mathrm{mm} \mathrm{Hg}^{\mathbf{b}}\right.$ & 73 & $72-76$ & 75 & $73-77$ & 0.286 \\
\hline
\end{tabular}

Note: ${ }^{\text {a Chi-square Test. }}{ }^{\mathbf{b}}$ Student's $t$ Test; ${ }^{\mathbf{c}}$ Mann-Whitney Test.

BMI: Body Mass Index; CI: Confidence Interval; DBP: Diastolic Blood Pressure; Md: Median; SBP: Systolic Blood Pressure.

It can be seen in Table 3 that there was a reduction in the daily frequency of consumption of stock broth cubes in the IG $(p=0.005)$. There were no significant changes in relation to the eating habits in the CG. After intervention, the reduction of stock broth cubes continued only for the intervention group over time $(\beta=0.615 ; p=0.016)$ (Table 4$)$. In addition, $73 \%(n=48)$ of IG participants $(n=66)$ reported that the messages were clear, 67\% $(n=44)$ said they were useful and $48 \%(n=32)$ stated they followed the guidelines (data not presented in a table). 
Table 2. Feeding practices of baseline participants. according to the allocation group. AvaliaSal Study. Vitória (ES), Brazil, $2017-2018$.

\begin{tabular}{|c|c|c|c|c|c|}
\hline \multirow{3}{*}{ Food Practices } & \multicolumn{4}{|c|}{ Allocation Group } & \multirow{3}{*}{$p$-value } \\
\hline & \multicolumn{2}{|c|}{ Intervention $(\mathrm{n}=87)$} & \multicolumn{2}{|c|}{ Control $(n=88)$} & \\
\hline & $\mathrm{n}$ & $\%$ & $\mathrm{n}$ & $\%$ & \\
\hline Change in eating habits in the last 6 months ${ }^{a}$ & 39 & 44.8 & 44 & 50.0 & 0.493 \\
\hline Habit of eating out ${ }^{a}$ & 80 & 92.0 & 77 & 87.5 & 0.332 \\
\hline Use of industrialized condiments ${ }^{\mathbf{a}}$ & 62 & 71.3 & 59 & 67.0 & 0.546 \\
\hline Use of natural seasonings ${ }^{a}$ & 85 & 97.7 & 88 & 100.0 & 0.153 \\
\hline Adding salt to prepared food or salad during meals ${ }^{a}$ & 44 & 50.6 & 35 & 39.8 & 0.151 \\
\hline Use of salt shaker on the table ${ }^{a}$ & 23 & 26.4 & 14 & 15.9 & 0.088 \\
\hline Use of stock broth cube ${ }^{a}$ & & & - & - & 0.236 \\
\hline Daily & 15 & 17.2 & 8 & 9.1 & - \\
\hline Weekly & 34 & 39.1 & 34 & 38.6 & - \\
\hline Monthly/ almost never & 38 & 43.7 & 46 & 52.3 & - \\
\hline Use of complete seasoning ${ }^{a}$ & & & & & 0.890 \\
\hline Daily & 7 & 8.1 & 8 & 9.1 & - \\
\hline Weekly & 15 & 17.2 & 13 & 14.8 & - \\
\hline Monthly/ almost never & 65 & 74.7 & 67 & 76.1 & - \\
\hline Grill/Fondor ${ }^{\circledast}$ use $^{a}$ & - & - & - & - & 0.779 \\
\hline Daily/weekly & 9 & 10.4 & 8 & 9.1 & - \\
\hline Monthly/ almost never & 78 & 89.6 & 80 & 91.9 & - \\
\hline Use of meat tenderizer ${ }^{a}$ & - & - & - & - & 0.536 \\
\hline Daily/weekly & 7 & 8.0 & 5 & 5.7 & - \\
\hline Monthly/ almost never & 80 & 92.0 & 83 & 94.3 & - \\
\hline
\end{tabular}

Note: a Chi-Square test; Complete seasoning: garlic+salt+additives.

Table 3. Participants' dietary practices. according to the allocation group at two time points. AvaliaSal Study. Vitória (ES), Brazil, $2017-2018$.

\begin{tabular}{|c|c|c|c|c|c|c|c|c|c|c|}
\hline \multirow{4}{*}{ Dietary Practices } & \multicolumn{10}{|c|}{ Allocation Group } \\
\hline & \multicolumn{4}{|c|}{ Intervention $(\mathrm{n}=87)$} & \multirow{3}{*}{$p$-value } & \multicolumn{4}{|c|}{ Control $(n=88)$} & \multirow{3}{*}{$p$-value } \\
\hline & \multicolumn{2}{|c|}{ Baseline } & \multicolumn{2}{|c|}{ Reassessment } & & \multicolumn{2}{|c|}{ Baseline } & \multicolumn{2}{|c|}{ Reassessment } & \\
\hline & $\mathrm{n}$ & $\%$ & $n$ & $\%$ & & $\mathrm{n}$ & $\%$ & $n$ & $\%$ & \\
\hline $\begin{array}{l}\text { Adding salt to prepared food } \\
\text { or salad during meals }{ }^{a}\end{array}$ & 44 & 50.5 & 50 & 57.5 & 0.263 & 35 & 39.8 & 32 & 36.4 & 0.678 \\
\hline Use of salt shaker on the table ${ }^{a}$ & 23 & 26.4 & 17 & 19.5 & 0.210 & 14 & 16.0 & 8 & 9.0 & 0.180 \\
\hline Use of stock broth cube ${ }^{a}$ & - & - & - & - & $0.005^{*}$ & - & - & - & - & 0.247 \\
\hline Daily & 15 & 17.2 & 7 & 8.0 & - & 8 & 9.1 & 12 & 13.6 & - \\
\hline Weekly & 34 & 39.0 & 29 & 33.3 & - & 34 & 38.6 & 27 & 30.7 & - \\
\hline Monthly/almost never & 38 & 43.7 & 51 & 58.6 & - & 46 & 52.3 & 49 & 55.7 & - \\
\hline Use of complete seasoning ${ }^{a}$ & - & - & - & - & 0.123 & - & - & - & - & 0.228 \\
\hline Daily & 7 & 8.0 & 4 & 4.6 & - & 8 & 9.0 & 7 & 8.0 & - \\
\hline Weekly & 15 & 17.2 & 11 & 12.6 & - & 13 & 14.8 & 10 & 11.4 & - \\
\hline Monthly/almost never & 65 & 74.7 & 72 & 82.7 & - & 67 & 76.1 & 71 & 80.7 & - \\
\hline Grill/Fondor ${ }^{\circledR}$ use $^{\mathrm{a}}$ & - & - & & & 1.000 & - & - & - & - & 1.000 \\
\hline Daily/weekly & 9 & 10.3 & 8 & 9.2 & - & 8 & 9.0 & 7 & 8.0 & - \\
\hline Monthly/almost never & 78 & 89.6 & 79 & 90.8 & - & 80 & 91.0 & 81 & 92.0 & - \\
\hline Tenderizer use $\mathrm{e}^{\mathrm{a}}$ & - & - & - & - & 1.000 & - & - & - & - & 0.375 \\
\hline Daily/weekly & 7 & 8.0 & 8 & 9.2 & - & 5 & 5.7 & 8 & 9.0 & - \\
\hline Monthly/almost never & 80 & 92.0 & 79 & 90.8 & - & 83 & 94.3 & 80 & 91.0 & - \\
\hline
\end{tabular}

Note: ${ }^{\mathrm{M}} \mathrm{M}$ Nemar test; ${ }^{*} p<0.05$; Complete seasoning: garlic+salt+additives.

Table 4. Generalized Estimated Equation Model on behavior change related to the frequency of stock cubes consumption. AvaliaSal Study. Vitória (ES), Brazil, 2017-2018

\begin{tabular}{lcc}
\hline Variable & B $^{* *}$ & Ready broth $p$-value \\
\hline Intervention/Control & 0.196 & 0.511 \\
Reassessment & 0.035 & 0.848 \\
Reassessment in IG & 0.615 & $0.016^{*}$ \\
Reassessment in CG & 0.035 & 0.848 \\
\hline
\end{tabular}

Note: ${ }^{*} p<0.05 ;{ }^{* *} \beta$ : B Coefficient; Variable outcome: ready broth: $\mathrm{n}=175$.

CG: Control Group; GEE: Generalized Estimated Equation; IG: Intervention Group.

Variable included in GEE: Stock cubes/Multinomial variable; Time (Assessment or Reassessment); Group (Intervention or Control). 


\section{DISCUSSION}

A reduction in the frequency of use of ready broth cubes in the IG was observed, demonstrating the potential of the $\mathrm{m}$-Health strategy on sodium consumption markers. Considering that a high percentage of the sample studied used ready broth cubes more frequently when compared to other processed seasonings, their use reduction could decrease sodium intake as much as $25 \%$, as observed in a study with a similar population [6].

In turn, health education can result in changes in lifestyle [8]. However, it is of major importance that these changes occur earlier in order to prevent diseases. Reducing sodium in the diet can not only prevent hypertension and cardiovascular diseases, but also impact overall mortality from all causes [1].

Most studies using m-Health technology are carried out with individuals with a disease. In England, messages were sent about blood pressure self-monitoring and changes in health behaviors, and after 12 weeks, a reduction in BP and body weight was observed, in addition to an improved diet [8]. In a study with pre-hypertensive patients, a reduction in sodium consumption was also observed [19].

Therefore, there is already evidence that $\mathrm{m}$-Health technology is effective in controlling some diseases, in addition to having good acceptance by users, which favors the implementation of this strategy in primary health care. In addition, it can increase resolution and impact health with a positive effect on lifestyle modification, through health practices and the establishment of a preventive care channel [20]. In this study, we identified a good acceptance regarding usefulness, clarity and followup, a result similar to that found in other studies $[8,10]$.

Behavior changes can contribute to improving health conditions and increasing consumption of healthy foods, but there is still no consensus on the effectiveness of the $\mathrm{m}$-Health strategy for some health practices, especially when related the reduction of salt and processed condiments consumption $[8,11,19]$. In this study, the reduction in the use of stock broth cubes in the Gl may be the first evidence that it is possible to prevent high sodium intake in the general population, considering that stock broth cube is one of the most widely used processed seasoning in food preparation. This condiment is used in different food preparations and contains monosodium glutamate in its composition. Therefore, it is a product that should be discouraged.

Although the study sample is not representative of the Brazilian population and the results cannot be extrapolated to other groups, it was possible to identify the potential of the intervention for its implementation in other contexts. This study may be considered the first $\mathrm{m}$-Health program carried out with adults in the Espirito Santo State, with the purpose of evaluating changes in dietary practices related to sodium consumption markers. Another possibility is the use of the materials developed in primary health care, as part of a program aimed at promoting healthy and adequate nutrition.

A possible limitation of this study may be the use of questionnaires, which can generate information bias; however, training and certification of interviewers was carried out. In addition, it was not possible to measure sodium consumption using the gold standard method (24-hour urinary excretion), due to operational and technical difficulties, just like other sodium-source foods were not assessed, as well as frequency of eating out and whether participants prepare meals at home. However, a study conducted with a university community identified a significant association between frequent use of processed condiments and higher estimated salt consumption, demonstrating the contribution of these products to increased sodium consumption [6]. 
In this study, there was a $21.1 \%$ loss of participants, a figure close to other studies with the same characteristics. It is worth mentioning that the validation of the sample size accepted in studies with individuals undergoing $\mathrm{m}$-Health intervention varies from 28 to 372 participants [11]. Thus, even with this loss, the number of participants was still within the accepted variation. In addition, such loss was similar in the two groups, since in the sensitivity analysis, no statistical differences were observed in any sociodemographic characteristics when comparing the groups before and after the participants' withdrawal.

Another potential limitation is the use of the Intention-to-treat analysis, since we assumed that individuals who did not attend the reassessment session did not change their eating habits after the intervention, as their data was imputed. This technique is used in intervention studies as a way to minimize losses, since the number of participants in the groups would remain the same. In this study, the losses in the intervention and control groups were similar in relation to gender and age group, thus they did not impact the final result.

Bearing in mind that the IG belongs to the same institution as the CG, it is possible that the participants shared information. However, the CG received the messages only after the second assessment, as provided for in the protocol.

\section{CONCLUSION}

A reduction in the frequency of stock broth cube use was observed in participants without a medical diagnosis of hypertension. The use of the m-Health strategy is feasible and could be reproduced in a similar population because it is an intervention that is easy to apply, low cost and well evaluated by users. The results found demonstrate the effect of the intervention using the $\mathrm{m}$-Health strategy, on health promotion and changes in dietary practices in connection with high sodium consumption.

\section{ACKNOWLEDGMENTS}

To Universidade Federal do Espirito Santo (UFES) nutrition students and to the study participants, to Coordenação de Aperfeiçoamento de Pessoal de Nivel Superior (CAPES, Coordination for the Improvement of Higher Education Personnel) Conselho Nacional de Desenvolvimento Científico e Tecnológico and (CNPq, National Council for Scientific Researches).

\section{CONTRIBUTORS}

AS PORTO contributed with to analysis, interpretation and writing of the manuscript. HX MARTINS and CP FARIA contributed with to interpretation of results and writing of the manuscript. MCB Molina contributed with to conception, planning, analysis, interpretation and writing of the manuscript. All authors approved the final version forwarded and declared that there is no conflict of interest.

\section{REFERENCES}

1. Cook NR, Appel LJ, Whelton P. Sodium Intake and all-cause mortality over 20 years in the trials of hypertension prevention. J Am Coll Cardiol. 2016;68(15):1609-17. https://doi.org/10.1016/j.jacc.2016.07.745 
2. Rauber F, Louzada MLC, Steele EM, Millet C, Monteiro CA, Levy RB. Ultra-processed food consumption and chronic non-comunicable diseases-related dietary nutrient profile in the UK (2008-2014). Nutrients. 2018(10):587. https://doi.org/10.3390/nu10050587

3. Bhat $S$, Marklund M, Henry ME, Appel L, Croft KD, Neal B, et al. A systematic review of the sources of dietary salt around the world. Adv Nutr. 2020;00:1-10. https://doi.org/10.1093/advances/nmz134

4. Perin MS, Cornélio ME, Oliveira HC, São-João TM, Rhéaume C, Gallani MCBJ. Dietary sources of salt intake in adults and older people: a population-based study in a Brazilian town. Public Health Nutr. 2019;22(8):1388-97. https://doi.org/10.1017/S1368980018003233

5. Louzada MLC, Ricardo CZ, Steele EM, Levy RB, Cannon G, Monteiro CA. The share of ultraprocessed foods determines the overall quality of diets in Brazil. Public Health Nutr. 2018;21(1):94-102. https://doi. org/10.1017/S1368980017001434

6. Oliveira LS, Coelho JS, Siqueira JH, Santana NMT, Molina MDCB. Relación sodio/potasio urinario y consumo de condimentos industrializados y alimentos ultraprocesados. Nutr Hosp. 2019;36(1):125-32. https://doi. org/10.20960/nh.02101

7. Sim I. Mobile devices and health. N Engl J Med. 2019;381(10):956-68. https://doi.org/10.1056/NEJMra 1806949

8. Salisbury C, Cathain AO, Thomas C, Edwards L, Gaunt D, Dixon P, et al. Telehealth for patients at high risk of cardiovascular disease: pragmatic randomised controlled trial. Research. 2016;356(2647). https://doi. org/10.1136/bmj.i2647

9. He J, Irazola V, Mills K, Poggio R, Beratarrechea A, Dolan J, et al. Effect of a community health worker-led multicomponent intervention on blood pressure control in low-income patients in Argentina: a randomized Clinical Trial. J Am Med Assoc. 2017;318(11):1016-25. https://doi.org/10.1001/jama.2017.11358

10. Bobrow K, Farmer AJ, Springer D, Shanyinde M, Yu L-M, Brennan T, et al. mobile phone text messages to support treatment adherence in adults with high blood pressure (StAR): a single-blind, randomized trial. Circulation. 2016;133(6):592-600. https://doi.org/10.1161/CIRCULATIONAHA.115.017530

11. Lee JA, Choi M, Lee $S A$, Jiang N. Effective behavioral intervention strategies using mobile health applications for chronic disease management: a systematic review. Bmc Med Inform Decis Mak. 2018;18(1):12. https:// doi.org/10.1186/s12911-018-0591-0

12. Stieger S. Facebook usage and life satisfaction. Front Psychol. 2019;10:2711. https://doi.org/10.3389/fpsyg. 2019.02711

13. Précoma DB, Oliveira GMM, Simão AF, Dutra OP, Coelho OR, Izar MCO, et al. Atualização da Diretriz de Prevenção Cardiovascular da Sociedade Brasileira de Cardiologia. Arq Bras Cardiol. 2019;113. https://10.5935/ abc. 20190204

14. Associação Brasileira de Empresas de Pesquisas. Critério Brasil 2015 e atualização da distribuição de classes para 2016. São Paulo: ABEP; 2015 [citado 11 fev 2019]. Disponível em: http://www.abep.org/criterio-brasil

15. Lo Bue E, Maugeri R, lacopino DG, Somma T, Graziano F. Other apps beyond WhatsApp. World Neurosurg. 2019;130:567. https://doi.org/10.1016/j.wneu.2019.05.086

16. Ministério da Saúde (Brasil). Guia alimentar para a população brasileira. Brasília: Ministério; 2014 [citado 11 mar 2020]. Disponível em: www.saude.gov.br/bvs

17. Ministério do Desenvolvimento Social e Combate à Fome (Brasil). Marco de referência de educação alimentar e nutricional para as políticas públicas. Brasília: Ministério; 2012 [citado 11 mar 2020]. Disponível em: http:// mds.gov.br/caisan-mds/educacao-alimentar-e-nutricional/marco-de-referencia-de-educacao-alimentare-nutricional-para-as-politicas-publicas

18. International Business Machines Corporation. SPSS Statistics for Windows. version 23.0. [software]. Armonk: IBM Corp; 2015.

19. Rubinstein A, Miranda JJ, Beratarrechea A, Diez-Canseco F, Kanter R, Gutierrez L, et al. Effectiveness of an mHealth intervention to improve the cardiometabolic profile of people with prehypertension in low-resource urban settings in Latin America: a randomized controlled trial. Lancet Diabetes Endocrinol. 2016;4(1):52-63. https://doi.org/10.1016/S2213-8587(15)00381-2

20. Graves L, Leung S, Raghavendran P, Mennito $S$. Transitions of care for healthy young adults: promoting primary care and preventive health. South Med J. 2019;112(9):497-9. https://doi:10.14423/SMJ.0000000000001017 